原著

\title{
保存血に於ける細菌励染の実験的研究
}

\author{
千葉大学腐政研究所（主任 相磯和嘉教授） \\ 小島 竜男
}

\section{EXPERIMENTAL STUDIES ON BACTERIAL CONTAMINATION IN BANKED BLOOD}

\author{
by \\ Tatsuo KozImA \\ Institute of Food Microbiology, Chiba University, Chiba \\ (Director: Prof. K. Aiso)
}

\begin{abstract}
The growth curves of three experimentally contaminated strains of Pseudomonas and one of Aerobacter aerogenes in banked blood were shown.

During first $24 \mathrm{hrs}$. after inoculation, the viable number of bacteria decreased remarkably on account of bactericidal activity of serum, but surviving cells started again to grow during the following 24 to 48 hrs., the growth being completed in 7 to 14 days.

Seventy-one per cent of 40 strains grew abundantly in banked blood when incubated at $5 \sim 6^{\circ} \mathrm{C}$, while only one strain among other water bacteria (21 strains of Achromobacter, Alcaligenes and Flavobacterium) multiplied under these conditions.

Therefore, it is obvious that pseudomonas is the most dangerous contaminant among water bacteria.

In order to explain the mechanism of shock syndrome developing after the transfusion of contaminated blood, the effects of intraveneous injection of washed bacterial cells into experimental animals were investigated.

A remarkable depressor action was demonstrated when the cell suspension of either Aerobacter or Pseudomonas was injected. On
\end{abstract}

the other hand, the action was not significant with Micrococcus. Should an accident occur, it is necessary to isolate the contaminated bacteria from the patient or after death.

The author demonstrated that if the contaminant was coli-aerogenes group organism, the causative agent was easily isolated from the human materials. However, the isolation was not successful in the case of pseudomonas, because the water forms of pseudomonas were destroyed in an early stage of injection.

\section{緒言}

我が国に於て1951年加藤教授によつて始めて血 液銀行吢設立されて以来，ここに 8 年の才円が経 過した。保存血利朋は今日益々盛んになると共に 此れが近代医学に貢献する事測り知れぬものがあ る.しかしその半面, 保存血輸血に伴う副作用も 少くない.此の中で細菌の濃厚污染を受けた保存 血輸血による副作用の報告が時折学会雑誌に発表 される様になつた。

1953年千葉大学に於ける保存血輸血による致死 事故を始めとして，現在迄に発表或いは確認され たものに，1955年 3 例，1956年 2 例，1959年 2 例 
（6月 1 日現在）がある.此れ等の事故例は外国 の文献を合わせると36例中21例が死亡しているの で致命率 $58 \%$ となり，如何に危険なものであるか が䂓がわれる.その他に輸血後, 病因不明のシ ョック症狀で死亡し，家族に此の事故の発覚を恐 れ，補償費の問題や法廷闘爭の繁雑を避ける意 味で世に出ず葬られてしまう事をも考え合わせれ ば，此の数字は更に高率になるであろう。

此の種の事故に対して当研究所に於ては相磯和 嘉教授1)の我が国第 1 例の報告を始めとして多く の研究報告がある. 又事故の原因となり得る污染 菌で保存血中から当研究所で分離同定された菌種 は約36株を数えているが，著者は保存血利用の盲 点とも云われる此れ等副作用の防止のため, 此の 問題に関する基礎的実験を行つたので茲に報告 し，御批判を仰ぐ次第である。

I . 水棲菌及び腸内細菌に於ける好泠菌の分布 保存血輸血事故で細菌の濃厚派染により発生す る事故の中, 報告されているものでは総べての事 故に於て, 輸血された保存血中に生きた細菌が 1 CC当り 1 億から数億含まれていた事は間違いない 事実である. 此の污染源が水, 土㙵, 空気, 器物 にあるため污染細菌の種類は水中菌, 土壤菌, 空 中菌と非常に広い範囲にわたつている. Braude 2)によれば表 1 に示す如く，広い意味での活染

表 1 血液銀行より搬出される前の39污染 血からの分離菌（Braude）

\begin{tabular}{|c|c|}
\hline 菌 種 名 & 泒染血の数 \\
\hline Staphylococcus & 21 \\
\hline coagulase (+) & 2 \\
\hline coagulase (一) & 19 \\
\hline Micr. Tetragenes & 4 \\
\hline B. alkaligenes & 3 \\
\hline Diphtheroid & 3 \\
\hline Str. viridans & 2 \\
\hline B. Subtilis & 2 \\
\hline Paracolon & 1 \\
\hline Enterococcus & 1 \\
\hline Ps. aeruginosa & 1 \\
\hline B. freundii & 39 \\
\hline 計 & \\
\hline
\end{tabular}

細菌はグラム陽性球菌が一番多く，グラム㓌性桿 菌が分難された例は 6 株であると云う。此の中グ ラム陽性球菌では.葡萄球菌, 連鎖球菌, 腸球菌や 非病原性のミクロコッカスがあり，又グラム陽性 桿菌では Diphtheroid, spore-forming bacteria 等であるが，グラム陰性桿菌では，Coli，aerogenes group, 水中菌として Pseudomonas, Achromobacter, Flavobacterium, 腐敗菌とし て Proteus, Serratia 等がある.

保存血液を採血して後早期に無菌試験をして見 ると污染菌には球菌類が多いが，保存も後期とな つてくれば若し検出されるとグラム陰性桿菌が多 い. 当教室の鴻3) は，各血液銀行で分離して送付 されて来た活染菌25株の細菌学的研究を行い報告 した。

表 2 某血液銀行で分離された污染 菌の同定 (小島)

\begin{tabular}{|c|c|}
\hline 菌 & 菌種数 \\
\hline Paracolobactrium aerogenoides & 5 \\
\hline Aerobacter & 5 \\
\hline Proteus morganii & 1 \\
\hline Serratia & 1 \\
\hline Pseudomonas & 1 \\
\hline Achromobacter & 1 \\
\hline Bacillus & $\frac{7}{5}$ \\
\hline Micrococcus \& Tetragenes \\
\hline 計,
\end{tabular}

著者は1958年京阪神の某血液銀行より送付され た污染菌26株の分離同定を行い，表 2 にある如き 結果を得た。此れ等の表に見る如くParacolon, Aerobacter, Escherichia, が比較的多く, Pseudomonas, Alcaligenes, Achromobacter, 等 も良く出現していて污染の实体を窅い知る事が出 来た。

一たん保存血中に混入した菌も普通は.凡そ次の 理由から保存中でその增殖は阻止される. 即ち 1 つは血清の 殺菌作用であり，他は低温保存であ る.併し不幸にして活染菌が血清の殺菌作用に抵 抗性のある菌か, 又は保存中に低温其の他の理由。 により殺菌作用が不活性化されるか, 又或いは派 染菌量の多い場合であつてしかもその菌が 4 〜 6 
表 3 污染血に因る輸血副作用と原因細菌

\begin{tabular}{|c|c|c|c|}
\hline 污 染 細 菌 & 事件 & \begin{tabular}{|l} 
患者 \\
数
\end{tabular} & 転帰 \\
\hline Escherichia & 5 & 5 & 死 4 , 生 1 \\
\hline Aerobacter & 3 & 7 & 死6, 生 1 \\
\hline Paracolobactrium & 3 & 4 & 死 4 \\
\hline Escherichia and Strept. & 1 & 1 & 死 \\
\hline $\begin{array}{l}\text { Pseudomonas and } \\
\text { Escherichia }\end{array}$ & 1 & 2 & 死1, 生 1 \\
\hline $\begin{array}{l}\text { Pseudomonas and } \\
\text { or E. freundii }\end{array}$ & 2 & 3 & 死 2 , 生 1 \\
\hline $\begin{array}{l}\text { Pseudomonas and } \\
\text { or Aerobacter }\end{array}$ & 1 & 1 & 生 \\
\hline $\begin{array}{l}\text { Pseudomonas } \\
\text { 外 } 3 \text { 種の菌の混合污染 }\end{array}$ & 1 & 1 & 生 \\
\hline Achromobacter & 2 & 2 & 死 2 \\
\hline Alcaligenes faecalis & 1 & 1 & 死 \\
\hline Diphtheroid & 1 & 1 & 生 \\
\hline Enterococcus & 1 & 1 & 生 \\
\hline 菌 不 詳 & 1 & 1 & 死 \\
\hline 記載なし & 2 & 7 & 死 2 , 生 5 \\
\hline
\end{tabular}

“Cの低温で増殖する能力を持つている菌種か菌株 である場合, 保存血中で増殖した時には $1 \mathrm{cc}$ 当り 数億にも達する訳で当然副作用け.避けられない。 現在迄の此の種副作用の報告を原因菌別にまとめ て見ると表 3 の如くなり, 污染菌の中多くのも のが冷蔵温度で増殖可能の菌であつて, 此の際の 励染菌はグラム陰性の低温菌株か, 若しくは中温 菌中の低温増殖様に限られている. 従つて我々は こっではグラム㓌性桿菌特に好泠菌である䖝光菌 を中心とした水棲菌と, 中温細菌である大腸菌群 の好冷菌種に問題の焦点を合わせて良いと考え る. 所謂中温菌と云われる細菌はその発育温度の 簌囲も狹く, $38^{\circ} \mathrm{C} \sim 27^{\circ} \mathrm{C}$ 以外は増殖しない菌種で あるが，中には $4 \sim 6{ }^{\circ} \mathrm{C}$ の低温で増殖可能の好泠 菌株が変異株として混在している.

Aerobacter, Escherichia freundii, Escherichia coli, 等の所謂 Coliform bacteria が事 故の原因菌であつたケースが非常に多いのは此の 低温変異菌によるためと思方れる。相磯教授4) は 当研究所に於て中温細菌として主として $27^{\circ} \mathrm{C} て ゙$ 培 養分離した非病原菌 403株について，1\%葡萄糖 ブイヨンを用いて $4 \sim 6{ }^{\circ} \mathrm{C} て ゙ 7$ 日培養して溷濁に より発育の如何を判定する方法で低温増殖株が
ぞの程度存在するかを調べたが，その結果，21株 $5.2 \%$ に好冷菌株が見られた。此の中，グラム除 性桿菌丈をとると $6.2 \%$ となり, 大腸菌, エロバ クター, プロテウス, 菌の何れにもその存在が証 明された。

水棲菌については自然界に於ける分布が広く， 污染の機会は極めて多いものである.例えば当效 室の鴻は，自然物から $0 \sim 4{ }^{\circ} \mathrm{C} て ゙ 2$ 週間培養して 釣菌した菌の 9 株の菌種别分布を見る実験を行つ ているが, 水棲細菌に属するものが圧倒的に多い。

著者は又同様の方法で後述した如くPseudomonas 40株, Achromobacter 4 株, Alcaligenes 7 株，(当教室長谷川，中村，志賀らが食 品，水，土塆から分離した）を用いて実験した。

II . 好冷菌の保存血中での增殖実験

好冷菌が保存血液の低温保存中に一定の速庴で 増殖をとげる事は，相磯5)，鴻3)等によつて実験 的な研究が発表されているが，著者は此の問題に ついて更に細い点を再検討した実験を試みた。

相磯等の低温菌の増殖曲線を見ると，菌移植 後 $2 \sim 3$ 日後増殖を始め, $4 \sim 7$ 日で対数期に達 し，8〜14日で定常期となつている.その形は大 体中温菌のそれと同様であつて，只あたかも中温 菌の増殖曲線の時間の目盛を日の目盛に換えた場 合と同様である．併し再者の曲線に相違のあるの は，誘導期にあたる移植後24〜48時間に於ける移 植菌の消長である. 此れも移植菌の多少により 違いのある事が推定される。此の点を追求して見 た。

実駼方法： 菌を $1 \%$ 葡萄糖ブイヨン中にて48 時間増菌培養し， $1 \mathrm{cc}$ 当り数千個〜数万個の割合 いにし，前もつて10cc宛分注した中試験管中のA C D液加血液に分注, 上く振晹混和し, 正確に 4 〜 $6{ }^{\circ} \mathrm{Cに}$ 保たれた電気冷蔵庫中に保存した。菌移 植後よく混和してその一部をとり移植菌数を菌数 計算し，その割合いを確かめ以後 2 時間，4恃 間，24時間，14日間の菌数の消長を観祭した。使 用した菌株は 4 株で Pseudomonas 3 株と Aerobacter BD 株 1 株である。

実験成績 : 
図1 A C D 液加保存血に於ける移植細菌の消長 (24時間以内, 移植菌量多き場合)

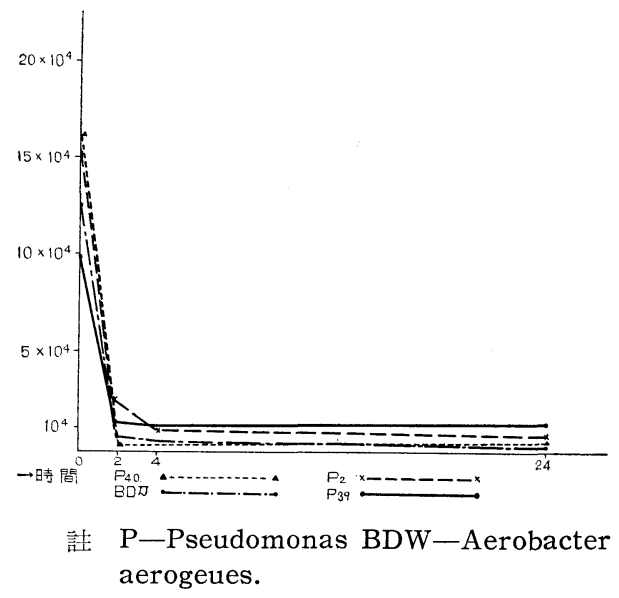

1. A C D液加保存血に於ける短時間の菌数の 消長

菌移植㤋倯々大量 $1 \mathrm{cc}$ 当り 10 万〜 15 万個前後と して，その直後より 2 時間， 4 時間，24時間の 菌数の消長を観察した。図 1 に見る如く各時間共 4 株の菌に於て菌数の激減を認めている。特に Pseudomonas 40に於ては 2 時間に於ては約 400 分の 1 と激減，24㭙間にて約 150 分の 1 と若干増 加している. Aerobacter BDW 株に於ても2 時 間にて 30 分の $1 ， 24$ 時間にて約16分の 1 と減少し ている. Braude の詳細なる実験によつては，室 温で被験菌の中グラム陽性菌の $47 \%$ ，グラム㓌性 菌の53\%が血液中で殺菌若しくは発育阻止が見ら れたが，此の作用は被験菌の菌種，菌株により著 しい差異があり，他方血液の側の個人差も認めら れている. 保存血の菌増殖は此の血清の殺菌, 発 育阻止作用が欠除したか，又は保存中に失われた 場合にのみ見られると論じている。

勿論実際の場合，血液の污染に関係する菌は 1 種と限つていないし， $4 \sim 6{ }^{\circ} \mathrm{C} に$ 於て増殖する菌 についての比較実験は信ずべき文献が無いのであ るが，污染菌の大部分は低温に於て血液中で死滅 するのであるが，若干のものが殺菌作用に抵抗し て増殖する能力のある事も明らかであるし，又低 温に於て殺菌作用そのものが部分的に不活性化さ れる傾向も否定出来ないのである.
図 2 移植菌量少き場合

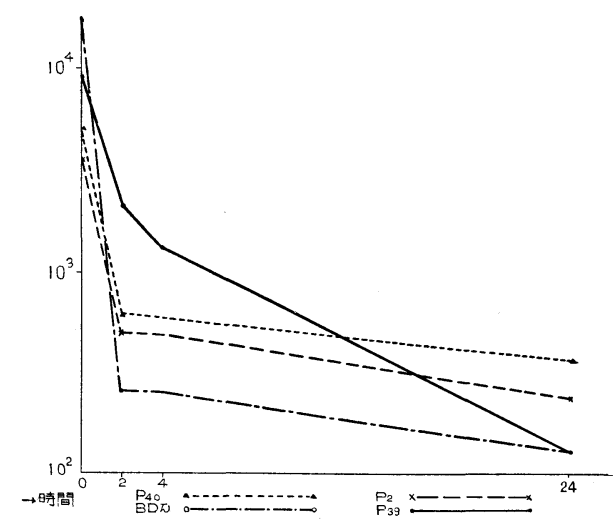

（註） P-Pseudomonas. BDW-Aerobacter aerogenes

园 3 污染細菌のA C D 液加血液中に於ける 低温增殖曲線

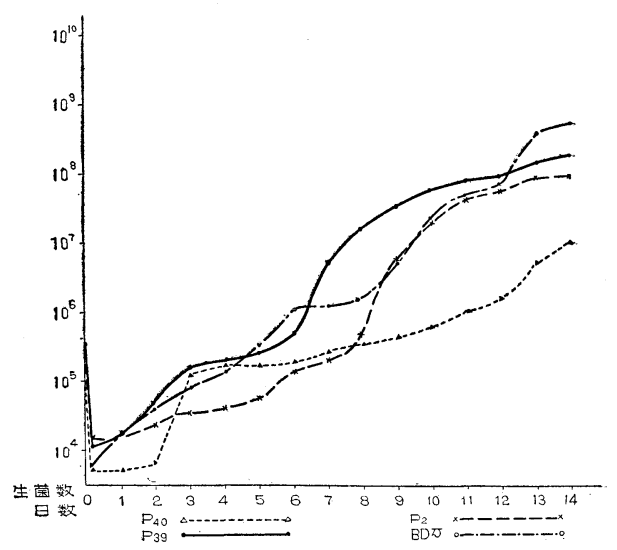

(註) P-Pseudomonas BDW-Aerobacter aerogens

2. A C D液加保存血に於ける短時間の菌数の 消長

次に菌数を $1 \mathrm{cc}$ 当り最低 5,600 個 から最高 12 ,000個程度として前回の 10 分の 1 の菌量を移植し て，同様にして 2 時間，4時間，24時間の菌の 消長を観祭した。困 2 に示した様に結果はAerobacter BDW 株に於ては約 100 分の 1 と激減せ る他, 皆一様に減少著明であつた。従つて此れ等 の成績を採用して 2 週間培養の増殖曲線を画くと 困3の如くなる。

\section{Pseudomonas 属菌株の低温増殖}


表 4 Pseudomonas 40 株の低温増殖 $\left(5^{\circ} \mathrm{C}\right)$

\begin{tabular}{|c|c|c|c|c|}
\hline \multicolumn{3}{|c|}{ ブィヨン中の発育 } & \multicolumn{2}{|c|}{$\begin{array}{c}\text { 人血液中での発育 } \\
\text { ( } c c \text { 当り菌数) }\end{array}$} \\
\hline \multirow{3}{*}{ 高 } & \multirow{3}{*}{ 度 } & \multirow{3}{*}{$23 *$} & $10^{8}$ 以上 & $7 *$ \\
\hline & & & $10^{7} \sim 10^{8}$ & 8 \\
\hline & & & $10^{6} \sim 10^{7}$ & 8 \\
\hline 中 & 度 & 10 & $10^{5}$ 以下 & 10 \\
\hline 軽度主 & v & & 0 & 0 \\
\hline
\end{tabular}

*数字は菌株数

水棲菌の代表的菌等である Pseudomonas の 保存血に於ける低温増殖については相磯, 鴻等に よつて報告されているが, 本研究所保存株のうち Pseudomonas と同定されている40株6) を使用 してブイヨン中の低温培養及び 保存血中の堌殖 を観察した。表 4 にあ汭た如くブイヨン $1 \mathrm{cc}$ 当り $10^{5}$ 程度に移植したがその㱠んどは. 7 日の保存期 間にて已に $10^{7} \sim 10^{8}$ 程度に迄発育し， maximum に達すると考えられる。此の菌株のうち中等度 以上に增殖した 33 株に $1 \mathrm{cc}$ 当り $10^{4}$ に移殖した場 合, 人血液中では $5^{\circ} \mathrm{C} 7$ 日培養で $1 \mathrm{cc}$ 当り $10^{6}$ 以 上に増殖した株が 23 株 $71 \%$ を示し， 10 株が $10^{5}$ 以 下であつた.ブイヨンの場合に比し人血では増殖 の比率は低下するが，それにしても如何に此の菌 が濃厭溛染の原因菌となり得る可能性の多いかを 示すものである。

4. Alcaligenes \& Achromobacter による 実験

本研究所菌株保存株中の Alcaligenes \& Achromobacter ${ }^{7)} 11$ 株を使用して本実験を行つた。 此の菌株は人血中に於て Pseudomonas に比し て低温菌でありながら, 増殖する比率が極めて低 い事が特徵的である.併し内外の文献により Achromobacter の事故例も2 例に見られるし, 相 磯教授によれば或る程度人血中にて増殖可能の株 がある事が判明しているので，染洉菌としてやは り注意する必要があるが, 只 Achromobacter は同定が非常に難かしく，Pseudomonas を愦 つて Achromobacter とする危険が少くないの で, 本菌の意義については合慎重な検討を行うべ きであろう。

5. Flavobacterium による実験
表 5 Flavobacterium 10 株の低温増殖

\begin{tabular}{|c|c|}
\hline 菌 株 & $\begin{array}{c}\text { (血 } 5^{\circ} \mathrm{C}, 7 \text { 日培着 } \\
(\mathrm{cc} \text { 当 } \text { の菌数 }\end{array}$ \\
\hline $\mathrm{F} 45$ & 0 \\
\hline $\mathrm{S} \mathrm{W}$ & 0 \\
\hline 19 & 0 \\
\hline 11 & 0 \\
\hline $\mathrm{F} 11$ & 0 \\
\hline 17 & 0 \\
\hline 24 & 0 \\
\hline $\mathrm{V} 11$ & $93 \times 10^{5}$ \\
\hline $\mathrm{F} 10$ & 0 \\
\hline 27 & 0 \\
\hline
\end{tabular}

本研究所菌株保存株中の Flavobacterium ${ }^{8)} 10$ 株を使用して本実験を行つた。此の際A C D液加 保存血中堌殖を認めたのは表 5 に示した如く 1 株 であつた。前回相磯教授は Flavobacterium 85 株中24株に好冷菌株を認めている.

\section{Proteus による実験}

本菌は腸内細菌の 1 つに数えられているが広く 自然界にも分布し, 蛋白分解作用の强い所から好 気性腐敗細菌の代表的なものである．健康な人の 腸にも10\%前後検出されるし, Proteus morganii 等は古くから小児の下痢症と関聯があると考 えられて居り，又食中毒菌の 1 つに当擬せられて いる.

$1 \%$ 加ブイヨン中にての 低温増殖を Proteus morganii 9 株を用いて实験した。全管に増殖を 認めたが人血中では 1 秼が偉かに $30 \times 10^{4}$ 程度に 増殖したかに見えた文で他は明な増殖は認めら れなかつた・此の中 Proteus morganii AY 株 は，相磯，柳沢教授等によつてサンマ榽干し中毒 検体に蓄積されているヒスタミンの産生源となつ ている菌株である。試みに本株を人血中に移殖し て $27^{\circ} \mathrm{C}$ で培養した場合の実験では.pH 6.8 を示し， ペーパークロマ!法にて測定し得る程ヒスタミン の産生は見られなかつた。

III. 污染菌輸入による血圧降下作用

前述の如く多数の污染菌の種類の中で, 低温で 増殖し血液 $1 \mathrm{cc}$ 当り $10^{7} \sim 10^{8}$ 以上に増殖するもの があるわけであるが，此の様な活染菌混入保存血 輸血による副作用の症狀は現在迄に報告せられて 
いる例に見る如く，污染菌の種類により 2 つに分 けられるそその 1 つは非病原性のグラム陽性球菌 交び桿菌, 他の 1 つは非病原性グラム陰性桿菌の 場合である．前者は比較的短時間で恢復し，全身 狀態も極度に重篤とならず，1 局部症狀，1 1 又は 2 の自覚他覚的症狀をもつて発病し，或る程度の 治療を要するか又は要せずして恢復するものであ る.

後者は全く重篤となり, 强力な治療をもつてし ても恢復しない場合が多い. 症狀は schock syndrome であり, peripheral vascular collapse である.輸血中或いは輸血後 1 時閒, 遅くも数時 間内に悪寒戦慄と共に血圧の急激な下降が始まり 悪心, 嘔吐, 発熱が必発である. 激しい下痢, 痤 孪様の腹痛，尿閉も屢々見られる．末梢部のチア ノーゼも顕著である。

此の症狀を実験的に簡單に再現するには，血 圧降下作用と発熱作用である，発熱については菌 体内発熱物筫パイロジェンの存在が証明されてい る．著者は此れ等の点につき次の如き実験を行つ た。

実験方法： $1 \%$ 葡萄糖ブイヨンにて供試細菌 を48時間培養後遠沈，水洗してこれを $3 〜 4$ 回繰 り返して得た菌体を科量, 湿菌量を定め, 食塩水 に浮遊させ此れを家息耳静脈中に徐々に注入し， 注入前血圧, 注入後の血圧を非観血的方法（福田 -川川式）血圧測定器にて測定，5 分又は10分毎 に記録を行つた。

1. Aerobacter aerogenes BD 株の場合 : 使用家鬼 $2.3 \mathrm{~kg}$ 今湿菌量 $80 \mathrm{mg}$ を注入するに徐々 に血圧下降起り，呼吸促迫となり，鼻尖はチア） 一ゼを呈し, 瞳孔は軽度に散大し, かつ動脈收縮 狀態著明となり，狂騒狀態となる，注入後 35 分に して最高血圧で $60 \mathrm{~mm} H \mathrm{~g}$, 最低血圧で $50 \mathrm{mmHg}$ の低下 を認む。侉此の狀態は 24 時間後も続き下痢激し く, 血圧は最高血圧 $40 \mathrm{~mm} H$, 最低血圧 0 にして率 妈激しく26時間にして繁死した（図 4).

2. Micrococcus 2A18-1 菌株の場合： 傎用家鬼 $3.0 \mathrm{~kg}$ 同様の方法にて湿菌量を稍々大 量 $200 \mathrm{mg}$ を蒙秋耳静脈内に注入した。注入後 25 分
図 4 污染血注射家䨘の血圧曲線 (Aerobacter aerogenes $\mathrm{BD}$ 株)

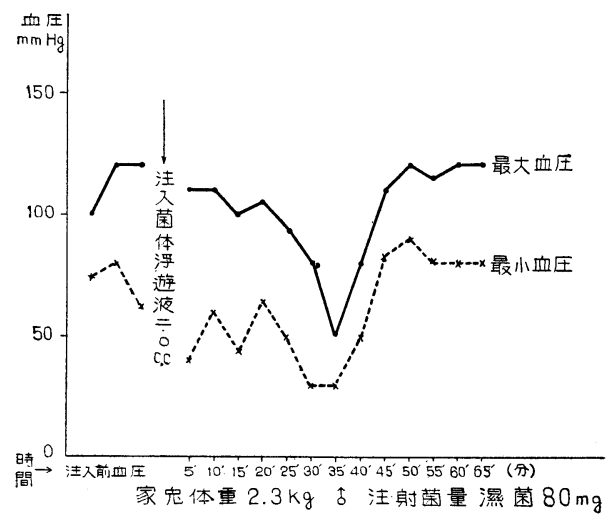

図 5 污染血注射家雭血圧曲線 (Micrococcus 2A18-1 株)

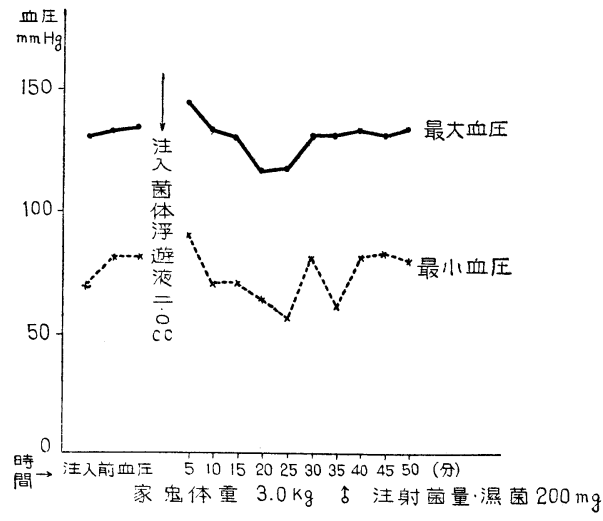

図 6 污染血注射家鬼血圧曲線

(Pseudomonas AHH-21株)

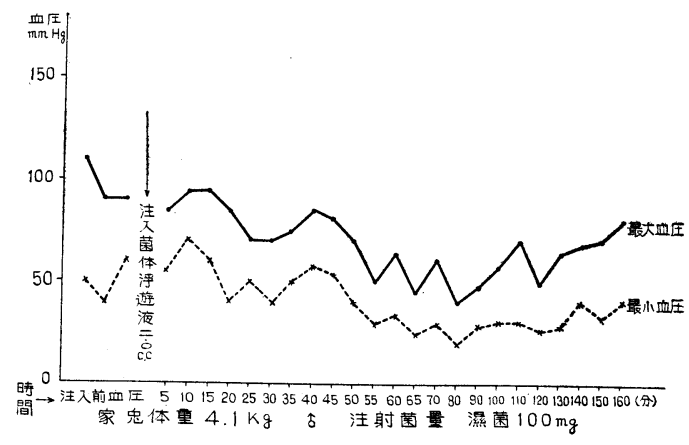

にして最高血圧で $15 \mathrm{~mm} H$ g, 最低血圧で $18 \mathrm{~mm} H \mathrm{H}$ の低 下を認めたに過ぎなつた。即ち血圧下降物質の 含有量は Coliform bacteria 並びに後述の Pse- 
udomonas に比較して顕著に少い事が判明した (図 5 ).

3. Pseudomonas fluorescens 21株の場合 :

使用家香 $4.1 \mathrm{~kg}$ 同様の方法にて湿菌量 $100 \mathrm{mg}$ を家鬼耳静脈に注入後，10分後から徐々に下降し 初め, 55分後に至りて本格的に血圧下降し, 注入 後80分に至る間に最大血圧で $54 \mathrm{mmHg}$, 最低血圧で $50 \mathrm{~mm} H \mathrm{H}$ の低下を認めた（図 6 ）.

IV. 輸血事故の際の污染菌の検查法

1. 分離菌の同定, 並びに低温増殖試験.

2. 副作用のあつた場合の残存血液，患者死体 からの分離.

3. 血液銀行或いは病院に於ける輸血前の無菌 検查等が主な問題となる．前述した如く保存血の 細菌が増殖しても此れを肉眼的に判別する事は困 難な場合が多い，従つて洉染血輸血の機会をなく すためには何等かの方法で輸血する直前迄に発見 する方途を考えなくてはならない，最も簡單で効 果があると思われるのは，輸血前に病院で直接塗 沫標本にて單染色又はグラム染色で鏡検する事で ある、しかし此れは輸血を絶対的と信頼している 医師の間では到底耳をかさぬ事実で，術前又は輸 血前の繁雑さにまぎれて実行出来ない事が多い樣 である。しかしやれ簡單な事であるし，少く共 濃厚泒染丈は誰でも容易に発見し得る。現に嬉野 病院に於て岩永氏等は輸血直前に此の方法で活染 を発見し患者を救つてる．従つて無菌検查はどう してもやらなければならぬ手続きである。

次に事故者の検查として，輸血に用いた血液の 一部 $5 \mathrm{cc}$ を氷室に 24 時間保存しておく丕慣があれ ば事故の時, 残存血液で迅速に原因の究明が出来 る。培養試験にては前述の菌を目標とする限りに 於て，血液寒天を用いる必要はない。普通のブイ ヨン寒天培地で Coliaerogenes group, pseudomonas は必ず捕捉出来る筈である，但し此の際 注意しなくてならないのは培養温度である.Coli-

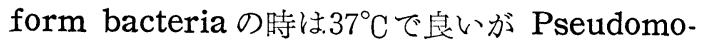
nas では Pseudomonas aeruginosa を除いて 他の菌種では $37^{\circ} \mathrm{C} て ゙ は$ 発育しないか，しても極め て弱い. $20 \sim 27^{\circ} \mathrm{C}$ の率卵器があると最も好都合で
ある. 尤も $20^{\circ} \mathrm{C}$ の兴卵器は普通のものでは調節が むずかしく，冬以外は使えない。実験室の室内温 度より少し高い $27^{\circ} \mathrm{C}$ ものがあればそれが一番良 い. $37^{\circ} \mathrm{C}$ 丈では好泠菌を落す危険が極めて多い. $4 \sim 6{ }^{\circ} \mathrm{C}$ の稃卵器でも良いが, 増殖に時間がか > り診断的の意味では遅い. 矢張り $20 \sim 27^{\circ} \mathrm{C}$ の睬卵 器で 24 時間, 時には48時間培養する必要がある。

次に患者又は死体から活染菌を分離する場合 には Coliform bacteria では容易に分離出来 るが, Pseudomonas の場合はその分離がかなり 困難である。此れに関して次の実験を試みた。 Aerobacter, Pseudomonas の増殖高度に達せし slautより菌をかき取り，菌量を測定しておき食塩 水に浮遊させて家鬼耳靜脈一注入した. Aerobacter aerogenes BD 株の培養菌体60mgを10ccの 食塩水に浮遊して家鬼に注射して60分，3時間， 6 時間毎に採血し, 死後各臟器について菌の分離 を行つて見ると，60分ではcc当り数万個の菌が証 明され，3 時間で減少し，6時間で再び数万個が 証明された。6時間30分で䇟死したので䀒，脾， 筲について分離を行つたが総ての例に於て多数の 菌が分離された。所が Pseudomonas fluorescens の90mgを同様に注射すると，60分，3 時間で は平板にも菌数算定用培地にも集落は見られず, 3 時間30分で繁死したが心, 䀒, 脾, 腎の各臟器 からも24時間培養では集落は見られなかつた。し かし48時間経過すると若干の集落が出現し，血液 $1 \mathrm{cc}$ 当り60個の集落を認めた。此の様にPseudomonas の場合は注意して丹念に観察しないと見 落す程に分離困難のものである。此の理由は納得 のいく程度には明らかではないが，生体に注入さ れた Pseudomonas は急速に死滅して行く事が 観察された。

此処で昭和31年11月 1 日〜30日間, 全国49力所 の大学病院, 国公立病院の協力により行つた保存 血細菌污染調查報告を東大輸血部の 調查統計9)10 により検討して見ると次の如くである。

1. 培養試験：チオグリコレート流動培地使用 4800本中, 細菌陽性数 79 本, 陽性率 $1.62 \%$ 。

2. 塗抹標本試験 : 3 週間迄 4 本中 2 本 $37^{\circ} \mathrm{C}$, 
2 本 $22^{\circ} \mathrm{C} \sim 25^{\circ} \mathrm{C}, 4527$ 本中 24 本, 陽性率 $0.53 \%$.

3. 培養温度別陽性例： 79 例中 $37^{\circ} \mathrm{C}$ み $\oplus は 37$ 本， $46.8 \% ， 37^{\circ} \mathrm{C} 25^{\circ} \mathrm{C}$ 共にÐは23本， $29.1 \% ， 25$ ${ }^{\circ} \mathrm{C}$ の円は19本，24.0\%となつて居る。此の值は Braude, Pittmann の調查に比して稍低い值が 出ているが此れが直ちに我が国の血液銀行の優 秀性を現わしていると見て良いかどうか疑問であ る。恐らく調査を繰り返し技術が熟練する事によ つて少し高い污染率が立証される事と推定される と相磯教授は報告されている。

4. 分離菌の同定並びに低温増殖試験：

己に述べた如く，Paracolobacterium を初め として, Aerobacter, Escherichia freundii, Escherichia coli 等の所謂 Coliform bacteria が事故の原因菌となる事が多いが，我々はBergy's manual 1948年版に従い分類を進めてい る. 只 Escherichia よりも乳糖を僬く分解する Paracolon 汇注意する事が必要である.Pseudomonas の同定については Protease pepton glycerol からなる螢光色素産生培地の使用が便利で ある。

分離菌の低温増殖試験には, A C D液個人血液 に $1 \mathrm{cc}$ 当り $10^{3} \sim 10^{4}$ 程度の菌を移殖して菌数を概

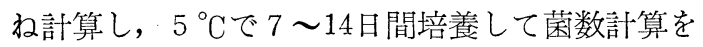
行う. 佮其の他の検查法として最近黑川等は輸五 直前に短時間にて活染の有無を検する方法とし て, 污染細菌の代謝産物を化学的に定性又は定量 測定する事, 歹び代謝過程中の酵素の反応を測定 する事により検出する事を試みた。同氏等は目下 実験続行中である。

考 按

保存血液の細菌汗染に因る輸血副作用は臨床医 学の立場から症候, 治療, 予防の問題として採り 上げなければならないのであるが，同時に衛生細 菌学の立場加も汗染経路, 唀染細菌の低温発 育, 副作用の発生機作等病因に関する面で研究の 対象となる分野が少くない。著者は後者の衛生細 菌学の側に立つて相磯研究室の此の方面の研究の 一環として海染細菌をめぐる諸問題について研究 を進めた。問題となる溛染細菌をPseudomonas
を中心とする水棲細菌と Paracolobacterum を 中心とする大腸菌群の 2 グループにしぼつた事に ついては，相磯教授等の再三に亘る報告で明確に なつておるので説明を要しない。

A C D 液個人血液中に上記の污染菌を移殖して 実験的に増殖曲線を画いて見た時，最初の 24 時間 に起る菌の消長については此れ迄詳細の報告はな かつた. 此の時期は普通の細菌の増殖カーブの誘 導期にあたるものではあるが，意味は全く異つて おり，低温と，血清の殺菌力に抵沉する斗爭の場 であつて, 少数の適応菌が撰択されそこから誘導 期が始まるわ汀である。

活染源としての Psychrophiles の分布, 腸内 細菌に於ける Psychrophilic strains の分布に ついて鴻3)の報告に次いで鬼集菌の分類の修正を まつて再検討し，ょり正確な数字を出す事が出来 た. 污染菌の輸入による重篤な shock 症状はそ の 1 つの玩れとして強い血圧降下を伴うものであ るので, 此の血圧降下原因物質が輸大菌の菌体 成分に含まれるのをかなり正しく認むることが出 来，その物質の分布が菌の種類によつて相違する 事を実験的に証明し得た。

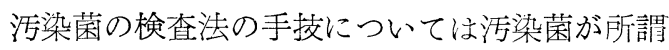
非病原細菌であるため，不慣れの人が多い事を子 想して詳しく記載した。

栃染菌の侵入経路, 侵入後の増殖阻止の実験は 特に行わなかつたが，此の問題については最近フ ライブルグ大学の Heilmeyer 内科教室の Matthes ${ }^{11)}$ 研究がある。それによると給血者の血液 を採取する場合，瓶内の陰圧のため，どこからか 外界の空気が入つて細菌污染を起す事が精密検查 で証明された。勿論 Matthes は今汽採取血液を 消毒する目的で20種以上の薬物汭用いられたが余 り効果なかつたが，空瓶を高圧蒸気釜で消毒する 時に瓶内に靜注用クロラムフェニコール（CM) の $3 \mathrm{mg} \%$ 大れて置くこととした. 加熱すると C Mの効果は $30 \%$ 減少するが， $1 l$ の血液に対して は0.1mg CMを加えた程度となる. Matthes が 特にCMを用いな理由としては，空気による細菌 污染としてグラム除性の大腸菌やPseudomonas: 
が多いので，此れ等に対して CMが他の抗生物質 よりも最も有力に作用する事, 又人体に抗原性 感作を起す事も少ない事，更に細菌の C M 耐性を 惹起する事も稀れである事等から用いたものであ る。その上靜注用 $\mathrm{CM}$ を葡萄糖液に溶かして血沈 を採取する前に, 或いは後に適当量瓶に入れて陰 圧を調節し，或いは除去し得るから特に選んだと 言う。同教窒では此の様にして 25000回の保存血 液を使用して 1 度も C M 感作作用を起さず, 又 従来見られた発熱や血行反応も $1 / 3$ に減じた。 又 CMで処理した滅菌陰圧硝子瓶1000本を最短80日 間も保存して後最も厳重に細菌検查を行つた所,

1 度も細菌は栃染を発見しなかつた事を追記して いる。

\section{総 括}

以上の実験成績を総括すると次の如くである.

（1）保存血液の細菌污染による輸血事故の場 合，原因細菌となる Pseudomonas, Coli-aerogenes groupの代表株を用いて A C D液加人血液 の $5{ }^{\circ} \mathrm{C}$ 保存時に於ける増殖の様相を精査すると， 移植直後加ら 24 時間迄は菌数は急速に減少し, 血 清の殺菌力と低温の影響を受けるが残存した少数 の抵抗菌から漸次増殖を始める．相磯の報告して いる増殖曲線の誘導期に相当する部分を修正し， より正確なカーブを作製する事が出来た。

(2) Pseudomonas 40 株中 $5{ }^{\circ} \mathrm{C}$ ブイヨンで 強く増殖する株は $82 \%$ ある. 此の中増殖の強か つた33株について人血中での低温増殖を見るとそ の71\%増殖しており，洉染菌として最も危險なも のである事が判明した。Achromobacter 4 株,

Alcaligenes 7 株, Flavobacterium 10株計21株 について同様の実験を行つたが Flavobacterium の 1 株が $93 \times 10^{5}$ まで増殖したのみで他は強い増 殖をましたものはなく，Pseudomonasに比して 低温増殖力の弱い事が明らかになつた。

（3）污染血による副作用の shock syndrome を説明するため, 污染菌 4 株をもつてその培 養菌の洗湺菌体食塩水浮遊液を家需血管に注入し て血圧の下降作用を見たが，Aerobacter, Pseudomonas の場合は強い血圧降下作用が見られた
が，Micrococcus の場合はその作用が緩徐であ つた.

（4）副作用発生時に患者から污染菌を分離す る場合, 大腸菌群の時は血液, 諸藏器から容易に 分離出来るが，Pseudomonas の場合は多くの 場合分離出来ない事を実験的に証明した。励染血 からの派染菌の発見をも含めて此れ等の污染菌を 分離する場合には20〜 $27^{\circ} \mathrm{C}$ の睬卵器を使用すべき である。

（5）某血液銀行からの溛染菌の同定を依賴さ れたが，グラム陰性桿菌のうち Paracolobacterium が多かつた。

稿を終るにあたり，終始，御愁篤な御指導と撖正な 御校閲を舓つた恩師相磯和嘉教授に心から感謝致すと 共に, 絶觉ず御協力を頂いた飯田助手始め教窒員諸氏, 並びに食中毒研究部, 小倉助教授, 都立豊島病院内科医 長名尾良憲博士, 長汐病院院長長汐達也氏, 及び当内科 富平輝夫，斎藤英夫両氏に深く感謝致します。尚本論 文の要旨は1957年第 5 回輸血学会総会に於て報告した。

\section{参考文献}

1) 相磯和嘉他：血液と輸血，1：128（1954）.

2) Braude. A.I, Sanford. J.P., Bartlett, J.E. \& Mallery, O.T.: J. Lab. \& Clin. Med., 39: 1902, 1952.

3) 鴻孝義: 千葉医会誌, 32 : 100, 1956.

4) 相磯和嘉: 外科研究の進歩, $5: 81,1958$.

5) 相磯和嘉：日本医事新報, 1956 .

6) 長谷川広吉：千葉医会誌, $33: 851,1958$.

7) 中村喜之助: 千葉医会誌, 33:842, 1959.

8）志賀信雄 : 千葉医会誌, $33: 128,1957$.

9) 日本輸血学会, 東大輸血部：血液と翰血, 4 : $131,1957$.

10）日本輸血学会, 東大輸血部：血液と輸血，4： 33, 1957.

11) Matthes: Dtsch. Med. Wschr., 84: 483, 1959.

12）岩永光陸他：医療, 9(12) : 10, 1955.

13）黑川正治他：日本輸血学会誌，5(5)：252, 1959.

14）山口晴一他 : 血液と輸血, $4(5): 244,1953$.

15）菅原香苗：血液と輸血, 4（6）: 340, 1958.

16）小島竜男他：千葉医会誌，34：205, 1959.

17) Officer, R.: Australia \& Newzealand J. Surg., $12: 111$.

18) Mollison, P.L.: Brit. Med. J., 1 : 529 \& 559, 1943.

19) Whitby, L.: In Blood Transfusion, Edited by G. Keynes, Baltimore, Williams and Wilkinson Company, p, 46, 1949.

20) Borden, C.W. \& Hall, W.H.: Newzealand. J. Med., 245 : 760, 1951.

21) Pittman, M.: J. Lab. \& Clin, Med., 42 : 273, 1952. 